Elsevier Editorial System(tm) for Biomass and Bioenergy

Manuscript Draft

Manuscript Number: JBB-D-07-00138R1

Title: Material flow accounting of an Indian village

Article Type: Research Paper

Section/Category:

Keywords: village ecosystem, material flow accounting, India, biomass, resource flows, social metabolism, forest, dematerialization, indicators, impact, ecoefficiency

Corresponding Author: Mr. Bruno Kestemont,

Corresponding Author's Institution: Statistics Belgium

First Author: Bruno Kestemont

Order of Authors: Bruno Kestemont; Marc Kerckhove

Manuscript Region of Origin:

Abstract: We are presenting material flow accounting and related indicators for an Indian adivasis village in 1983 (Sarowar, Dangs, Gujarat). It gives a point of comparison with modern nation-wide material flow accounting. The aim is to test the feasibility of indicators of dematerialization of the economy in poor economies. We measured the annual material flows within the Sarowar village (670 inhabitants) in 19821983. The method was a combination of surveys, real time measurements, indirect measurements and laboratory dry matter measurements. The results were translated into recent concepts of material flow accounting (MFA), and compared with nation-wide studies. The total material requirement (TMR) of Sarowar (excluding air and water), USA, Japan, Germany and The Netherlands is respectively about 5, 84, 46, 86 and 84 tons per capita per year. The input (all biotic materials are expressed in tons of dry matter per capita per year) totalised 15,8 t DM cap-1 y-1 in Sarowar, which consists mainly of air (11 t cap-1 y-1) and biotic 
primary materials (4,1 t DM cap- $1 \mathrm{y}-1)$. The latest was composed of $29 \%$ of pastures, $25 \%$ of branches for field burning, $35 \%$ of fuel wood, $6 \%$ fodder, $1 \%$ of construction wood and $4 \%$ of grains. The outputs ( $15.8 \mathrm{t}$ cap-1 y-1) were dominated by CO2 (15.1 t cap-1 y-1). In contrast, the output of The Netherlands (66.8 $t$ cap$1 \mathrm{y}-1)$ is dominated by export with air emissions (19t cap-1 y-1), export (16 t cap-1 y-1) and embedded export (29t cap-1 y-1). The apparent ecoefficiency (kg per US dollar, excluding air and water, including hidden flows) is 70, 3, 3, 3 and $3 \mathrm{~kg} \$-1$ respectively for Sarowar, Japan, USA, Germany and The Netherlands. The corrected ecoefficiency using Purchasing Power Parity is less contrasted with respectively 18, 3, 3, 4 and $3 \mathrm{~kg} \$-1$. Traditional human ecosystem measurements can serve as a basic comparison point, and as a test for dematerialization indicators. The limit of the indicator of ecoefficiency resides in the different degrees of monetarization of the economies. In less monetarized economies, this indicator is highly biased by the underlying non-market material flows. We discuss the use of ratios of non-substituable factors in dematerialization assessment and we suggest the use of use multicriteria analysis instead. 
Cover letter: Revision of "Material flow accounting of an Indian village"

To: Biomass \& Energy

Date: $10 / 5 / 7$

Dear editor and referees,

Thanks for your suggestions.

Fundamental suggestions:

I added a paragraph and some references on quality of air emissions resulting from incomplete combustion of open burning (in the discussion), and a sentence in the conclusion.

I also mentioned the quality critic in solid flows in general.

I added some more details in the "Material and method" chapter and in the discussion part.

Style suggestions:

I changed the format of units (using $\mathrm{t}^{-1}$ for example).

I moved old footnotes to the core text.

An English native speaker corrected English.

I explained the acronyms within the summary and in various parts of the text.

I added some keywords.

Best regards,

Bruno Kestemont

Tel 32-2-54866 61

e-mail: bruno.kestemont@economie.fgov.be 


\section{Material flow accounting of an Indian village}

2 Bruno Kestemont* and Marc Kerkhove**

3 *Université Libre de Bruxelles, Statistics Belgium, 44 rue de Louvain, 1000 Brussels,

4 Belgium (bruno.kestemont@economie.fgov.be). Tel: 3225486661. Fax: 3225486415.

$5 \quad * * \mathrm{CNCD}, 8$ rue du Commerce, 1000 Brussels, Belgium.

6 Keywords: village ecosystem, material flow accounting, India, biomass, resource flows,

7 social metabolism, forest, dematerialization, indicators, impact, eco-efficiency

\section{Abstract}

1. We are presenting material flow accounting and related indicators for an Indian adivasis village in 1983 (Sarowar, Dangs, Gujarat). It gives a point of comparison with modern nation-wide material flow accounting. The aim is to test the feasibility of indicators of dematerialization of the economy in poor economies. We measured the annual material flows within the Sarowar village (670 inhabitants) in 1982-1983. The method was a combination of surveys, real time measurements, indirect measurements and laboratory dry matter measurements. The results were translated into recent concepts of material flow accounting (MFA), and compared with nation-wide studies. The total material requirement (TMR) of Sarowar (excluding air and water), US A, Japan, Germany and The Netherlands is respectively about 5, 84, 46, 86 and 84 tons per capita per year. The input (all biotic materials are expressed in tons of dry matter per capita per year) totalised 15,8 t DM cap $\mathrm{y}^{-1}$ in Sarowar, which consists mainly of $\operatorname{air}\left(11 \mathrm{t} \mathrm{cap}^{-1} \mathrm{y}^{-1}\right)$ and biotic primary materials $\left(4,1 \mathrm{tDM}^{-1} \mathrm{cap}^{-1} \mathrm{y}^{-1}\right)$. The latest was composed of $29 \%$ of pastures, $25 \%$ of branches for field burning, $35 \%$ of fuel wood, $6 \%$ fodder, $1 \%$ of construction wood and $4 \%$ of grains. The outputs $\left(15.8 \mathrm{t} \mathrm{cap}^{-1} \mathrm{y}^{-1}\right)$ were dominated by CO2 $\left(15.1 \mathrm{t} \mathrm{cap}^{-1} \mathrm{y}^{-1}\right)$. In contrast, the output of The Netherlands $\left(66.8 \mathrm{tcap}^{-1} \mathrm{y}^{-1}\right)$ is dominated by export with air emissions $\left(19 \mathrm{tcap}^{-1} \mathrm{y}^{-1}\right)$, export $(16 \mathrm{t}$ $\left.\operatorname{cap}^{-1} \mathrm{y}^{-1}\right)$ and embedded export $\left(29 \mathrm{tcap}^{-1} \mathrm{y}^{-1}\right)$. The apparent eco-efficiency (kg per US dollar, excluding air and water, including hidden flows) is $70,3,3,3$ and $3 \mathrm{~kg} \$^{-1}$ respectively for Sarowar, Japan, USA, Germany and The Netherlands. The corrected eco-efficiency using Purchasing Power Parity is less contrasted with respectively 18, $3,3,4$ and $3 \mathrm{~kg} \$^{-1}$. Traditional human ecosystem measurements can serve as a basic comparison point, and as a test for dematerialization indicators. The limit of the ind icator of eco-efficiency resides in the different degrees of monetization of the 
economies. In less monetized economies, this indicator is highly biased by the underlying non-market material flows. We discuss the use of ratios of nonsubstitutable factors in dematerialization asses sment and we suggest the use of use multi-criteria analysis instead.

\section{Introduction}

The Resource Flows [1,2] concept developed by the World Resources Institute, addresses the Total Material Flow (TMF) underlying the economic process. The set of indicators that it produces has a certain political success among OECD countries. The European Commission is for example drafting a Regulation that would oblige the National Statistical Institutes to produce material flow accounting for each country. A Material Flow Accounting framework can be applied on several spatial scales, from supra-national entities to sectors, cities or regions [3]. It can also be used for temporal or historical comparison.

The idea is to tend towards a more efficient and sustainable development: to produce more human well being using less natural resources, i.e. decoupling economic growth from material use. This idea comes from the recognition that there is a material (natural) limit to growth [46].

Measuring the environmental/economic decoupling combines classical methods from economics (how to measure economy?) and from human ecology. For precursor studies of human ecology, see Odend'hal[7] and Duvigneaud[8].

The Total Material Requirement (TMR) measures the global pressure of primary matter on natural systems by summing the primary matter input expressed in tons, including the ecological rucksacks [9]. A light version of these accounts distinguishes the Direct Material Input (TMR minus hidden flows) and the Total Material Output that includes emissions (in air, water, waste) and goods exports. In omitting hidden flows (thus the impact of imports on material extraction in the rest of the world), this light version is not suitable for deriving sustainability indicators, since an apparent dematerialization could occur in case of dislocating of heavy productions to the rest of the world. However, in an international statistical work, such an approach could be cheaper to conduce, providing the TMR afterwards is calculated by consolidating the results of all trading countries to gether. The hidden flows are typically asso ciated with extraction activities, harvesting or infrastructure development [1]. Eurostat distinguish es the foreign hidden flows (or indirect flows, associated with import-export of primary matter), and domestic hidden flows (unused extraction) [10]. TMR is generally calculated exclud ing water flows but with biotic material expressed in fresh 
weight, which is debatable. Air flows are often excluded from the TMR indicators, the exclusion of which is also debatable in a context of a problematic atmospheric cycle. The main reason to exclude air and water flows, or at least to present them separately, is that they represent enormous mass flows (one order of magnitude more than other materials)[10].

The first national studies in developed countries show that, for example in Germany [11], -About $50 \%$ of the Direct Material Input comes from outside the country, 50\% from domestic environment

-The material input is of an abiotic nature, mainly solid (from which there is a non-used part) and about $15 \%$ gaseous (mainly $\mathrm{O} 2, \mathrm{~N} 2$ )

-About $15 \%$ of the input is used to raise the material stock in economy, the remaining part being emitted in the environment (or marginally exported).

-These emissions are mainly solid (about 60\% land filled waste), gaseous (about 25\%, mainly $\mathrm{CO} 2$ ) and to water (about 10\%)

-The recycling is small

Few traditional village level ecosystem studies had been published in the time of our field research: a study of a Bengali village [7], another in Gujarat [12], in Tamil Nadu [13], in Karnataka [14-16], two in Africa [17, 18], and several village studies in China from 1978 onwards. Recent works concentrate either on agricultural practices [19, 20] or energy efficiency [21-26]. Some "pure" ecosystem [27] or material flows studies [28] were published more recently, always with socio-economic or sustainable development goals. Village-level studies on ecosystem functions [29] are also relevant.

\section{Material and method}

We tested the method and indicators for the case of Sarowar (N 20॰50’21”, E 73³6’31'), a quasi-autarkical Indian village, situated in the mountains of the State of Gujarat, in the Dangs district, on the road Ahwa-Pimpri-Sarowar-Kalibel-Vyara, $30 \mathrm{~km}$ from Ahwa. The Dangs district is a hilly area with several plateaus ranging from 300 to $700 \mathrm{~m}$ of altitude[30]. It makes the transition between the Gujarat plain and the Sahyadris Mountains. The rock is basaltic (Deccan trap). The mean temperature in Ahwa $(549 \mathrm{~m})$ is $24,9^{\circ} \mathrm{C}$ and the mean rainfall is $2076 \mathrm{~mm}$. The rainy season lasts 5 months (May-September), the dry season 7 months. According to Köppen's classification, the climate is of type Aw 7-8 with a tendency to Am (monsoon). The hills are covered with a forest of teak (tectona grandis) and 
bamboo (dendrocalamus strictus). According to Champion's classification, it is a South Indian tropical wet deciduous forest (group 3A), a subdivision Semi-humid teak forest[30]. Exploitable trees are mainly teak (54\% of trees of circumference bigger than $120 \mathrm{~cm}$ ), terminalia tomentosa, and pterocarpus marsupium. Other common trees are garuga pinnata and lannea coromandelica. Climbing plant species are numerous, with millettia racemosa, butea superba etc. More than 300 medicinal species were identified, of which about 100 were used[30].

One can distinguish dry and clear forest[31]. At the time of the study (1982-1983), all the land was either reserved or protected. In the reserved forest, limited tree exploitation was a monopoly of the government but the people were allowed to trim the trees once a year and use the branches for fertilizing their fields. The protected forest was a natural reserve financed by the World Wildlife Fund, with a prohibition of agriculture and some limited timber exploitation by government. This special status was justified by the presence of tigers (Panthera tigris). Other noticeable mammal species were panthera pardus, melursus ursinus, sus scrofa, hyena hyena, and cervus unicolor. More than 120 bird species were identified in the district[30].

The peasants were not allowed to cut the trees, which were governmental property. They cut the branches and burned them onto the field with the purpose of pest control and fertilizing (like in shifting cultivation) but without the inconveniences of clear-cut (erosion, declining fertility etc). This method is called essartage in French (the English term fire agriculture is not appropriate).

Animist tribes, mainly Kokeni, Warelis and Bihls, and a few non-tribal civil servants coming from other parts of Gujarat inhabited Sarowar village. The population was 692 inhabitants corresponding to an equivalent of 670 full time inhabitants (taking in to account their rate of presence in the village). They could benefit from a luxurious forest, either directly or indirectly via their cattle, which could freely pasture with in it. The cultivated area per capita in different households varied between 0.15 and 1.7 ha cap $^{-1}$ with a mean of 0.7 ha cap ${ }^{-1}$. Animal traction was the main purpose of animal breeding, along with milk production - the residents were mainly vegetarians and limited the meat (chicken) consumption to animist ceremonies. The total annual revenue of Sarowar was estimated 465819 INR (70\% of it expended in local shops)[32]. The exchange rate was 10 INR per USD in 1983 [33] which gives a mean monetary revenue (in 1983 prices) of $70 \$$ cap $^{-1} \mathrm{y}^{-1}$.

We used previous data that we collected in 1982-1983 [32, 34]. At that time, we intended to describe a rural human ecosystem. We collected data using different methods, from direct 
133 measurement to surv eys among the inhabitants, and literature. We stayed 7 months in the

134 village during the dry season. The surveys by interview consisted in a combination of a

135 census for quantitative data (population, cattle, agricultural products etc) and a sample for

136 measurements (house, kitchen garden, fuel wood, etc) or open questions on the consumption

137 pattern. We identified four main socio-economic classes: landless farm workers, farmers, civil

138 servants and others. This was then used as post-stratification in order to extrapolate our

139 sample results. We weighed a representative sample of people ( $20 \%$ of the population) in

140 order to calculate the total anthropomass using a function of sex and age pyramid. This was a

141 pleasant way to introduce the interviews in many households. Combined with the typical

142 labour force patterns, this was useful to estimate the feeding energy needs using FAO-WHO

143 tables[35]. The three shopkeepers were all surveyed on their annual imports, exports and sales

144 in quantity and prices.

145 The field measurements consisted on transects to estimate the land pattern, and field sampling

146 to estimate the productivity. During the dry season, it is possible to collect data both about

147 harvesting (and related primary productivities) and about the preparation of fields (mainly

148 branch cutting for burning in the fields). We followed farmers and workers during the

149 harvests in order to measure the quantities collected per ha, the relation between grains and

150 other parts of the plants, the quantities taken away or released onto the field etc. From grain,

151 fodder and wood quantities estimated from the census, it was thereafter possible to calculate

152 various ecosystem flows. Samples of diverse biotic flows and stocks were also taken away for

153 laboratory analysis (dry matter and main chemical elements) later on. The quantities measured

154 (with a great variability amongst fields and time of harvest) were useful to validate the survey

155 results and deductions.

156 We translated this data into a conventional ecosystem flow chart, then in to modern material

157 flow accounting concepts.

\section{Results}

159 The biotic materials represented the major part of the inputs of the economy as defined by the

160 village Sarowar, its fields and the used part of its natural environment. If we had limited the

161 study to marked exchanges, the flows would have been negligible in this largely autarkic

162 economy. Figure 1 represents the material flows within this ecosystem, expressed in tons of

163 dry matters. We distinguished the subsystem "village" with its kitchen gardens (15 ha), the

164 fields (subsystem "ager", $239 \mathrm{ha}$ ), and the natural and semi-natural areas including the forest

165 and pastures (subsystem "silva+saltus", 206 ha). The domestic animals (and marginally 
166 humans and wild animals) travel from one subsystem to the other and represent the

167 connecting elements. Permanent forest cover and traditional agricultural practices relatively

168 limited erosion. However, with potential alternative management such as deforestation and

169 modern cultural practice, this element could become relevant in a possible future.

170 The ecosystem study showed the importance of forest products, main ly in the shape of

171 firewood (892 tons of dry matter per year), pasture (estimated $740 \mathrm{t} \mathrm{DM} \mathrm{y}^{-1}$ ), branches for

172 field preparation or essartage ( $640 \mathrm{t} \mathrm{DM} \mathrm{y}^{-1}$ from forest and field trees) and wood export by

173 the forestry company $\left(200 \mathrm{tDM} \mathrm{y}^{-1}\right)$ [34].

174 We measured a significant higher yield of paddy in the surrounding of isolated trees $(2.65 \mathrm{t}$

$\left.175 \mathrm{DM} \mathrm{ha}^{-1}\right)$ than in semi-open land $\left(2.25 \mathrm{t} \mathrm{DM} \mathrm{ha}^{-1}\right)$ of the same plot. Open land yields in other

176 plots of the same village provided respectively 500 and $700 \mathrm{~kg}$ paddy (dry matter) per ha.

177 Translated into the terminology of material flow accounting, the results of this study provide

178 the data presented in table 1. The data from Netherlands is presented in the same table in

179 order to give an element of comparison. The economic space is defined here everything that

180 has to do with humans, the village or domestic animals. The fodder flows within the forest are

181 therefore included, but the nutriments taken by the plants within the soil are not included

182 because it represen ts a natural service almost independent from direct human activities. This

183 distinction can be debated, but it does not change fundamentally our results. We keep the dry

184 matter unit: for biotic flows, this restriction avoids the fluctuations due to wet content

185 variability. If long distances were involved, for instance, on the level of a country, the use of

186 fresh matter could be justified from a transport problem point of view. Water flows are

187 omitted in both results, following European recommendations [10].

188 The main difference in MFA between Sarowar and the Netherlands is observed in

189 import/export, which is linked to the degree of opening of these economies. The Sarowar

190 village is less open to the outside economy than the full (small) developed country.

191 As expected, the autarkical village consumes more primary biotic material per capita (4.1 $\mathrm{t}$

192 DM cap $\left.^{-1} \mathrm{y}^{-1}\right)$ than the Netherlands $\left(0.4 \mathrm{t} \mathrm{DM} \mathrm{cap}^{-1} \mathrm{y}^{-1}\right)$. This is due to a relatively extensive

193 use of luxurious natural resources in contrast with the relatively efficient use of domestic

194 scarce natural resources in a very densely populated country like the Netherlands (470 cap

$195 \mathrm{~km}^{-2}$, against Sarowar $136 \mathrm{cap} \mathrm{km}^{-2}$ ). You can note that, due to the protection status of the

196 Dangs forest, and the prohibition of tree cutting, the natural system was far from over-

197 exploited in Sarowar. Compared with traditional extensive cultivation in equatorial Africa

198 (shifting cultivation), this cultivation system is relatively intensive and efficient. We are thus 
not comparing a full extensive system with an intensive one, but a "traditional" intensive

200 system with a modern one.

201 We consider the erosion due to traditional practice as comparable with the background natural

202 erosion in this hilly area (possible $24.15 \mathrm{tha}^{-1} \mathrm{y}^{-1}$ are not taken in to account as economic

203 flows). This estimation is empirically based a detailed study in a Chinese context: an erosion

204 of $24.15 \mathrm{tha}^{-1} \mathrm{y}^{-1}$ with traditional cultivation techniques, compared to $42.21 \mathrm{tha}^{-1} \mathrm{y}^{-1}$ from

205 other plot monitoring studies in a similar area, shows that the traditional farming system has

206 effectively conserved soil on the slope land there in the past decades [19]. With a modern or

207 extensive shifting cultivation scheme, Sarowar would probably add about $18.06 \mathrm{tha}^{-1} \mathrm{y}^{-1}$

208 erosion, or $4316 \mathrm{t}$ on the fields, and $5 \mathrm{t} \mathrm{cap}^{-1}$ additional material requirements.

209 The atmospheric inputs and outputs are remarkably of the same order of magnitude between

210 the compared systems. In order to build comparable results with the Netherlands, we only

211 included $\mathrm{O} 2$ as an input and $\mathrm{CO} 2$ as an output. However, $\mathrm{CO} 2$ as an input of biotic production

212 and $\mathrm{O} 2$ as its output could be included in both systems, as beneficial material flows: "natural

213 service production" for the economy. Concerning Sarowar, the volume of atmospheric inputs

214 and outputs is due to the wood incineration for cooking or field fertilizing. If the cooking is

215 relatively efficient due to the work cost neces sary to transport wood from the forest to the

216 village, the field burning of branches supposes a "non efficient" use, from the point of view of

217 energy efficiency.

218 The important use of domestic animals as source of milk, power force and high quality

219 fertilizers explain the major part of the non-energetic material flows identified in Sarowar.

220 The stock variation of the economy is remarkably low in Sarowar $\left(+0.1 \mathrm{t} \mathrm{cap}^{-1}\right)$ if compared

221 to the Netherlands $\left(+5.0 \mathrm{cap}^{-1}\right)$.

\section{Discussion}

223 The literature on material flow accounting tends to concentrate on solid and product flows, 224 expressed in total absolute weight. We are far from traditional human ecosystem studies, 225 which quantify many possible flows. This choice is driven by the policy-oriented nature of 226 material flow analysis: limiting the analysis to the impacts of the economy (i.e. human 227 activities). The further limitation to non-air and non-water flows is driven by pragmatism: it is 228 cheaper to exclude many flows in a first analys is. Moreover, on a national scale, solid or 229 product flows are easier to estimate from existing trade and production statistics. Air and 230 water flows are of a greater magnitude and their exclusion helps to focus attention on more 231 "qualitative" material flows included in solids and products. However, the qualitative aspect 
is certainly not addressed in solid and product material flows, which remain dominated by, for

233 example, inert materials from construction. Qualitative material flows are of greater

234 importance for the environment. For example, flows of toxic compounds can have greater

235 environmental or health impacts than big amounts of stones or grounds. From this point of

236 view, we think that air and water should not be excluded from (even quantitative) material

237 flow analysis or "social metabolism" studies. The transportation of pollutants in air or water is

238 certainly more relevant from the health or environmental perspective than the transportation

239 (by economy) in solid forms. If material flow analysis could help as a first approach to the

240 impact of economy on the ecosystem, therefore we think that air and water flows should not

241 be excluded. Human perturbation of water and atmospheric cycles are two of the major global

242 problems today [36, 37].

243 A first quantitative study including air flows, such as the one we did for Sarowar, should not

244 elude the hidden problematic of qualitative flows. For example, open burning in "essartage"

245 would engender, in terms of particulates and products of incomplete combustion (on health

246 and on climate change), effects considerably greater than the sole $\mathrm{CO} 2$ emissions [38-41]. On

247 the other hand, if technology and for example improved hooves [42] could increase the eco-

248 efficiency of specific processes such as burning in developing and developed countries, the

249 latter could have, and actually have, a bigger impact on global environment [36, 43, 44] due

250 to a bigger quantitative material intensity.

251 It is questionable whether field burning should be included or excluded from the economic

252 process, since this only shortens the natural cycle (the related emissions would anyway end

253 within the ecosystem). The recent European waste statistics regulation for example excludes

254 the within farmland ecosystem recycling from the waste incinerations statistics [45]. For the

255 same reason as above, we plead for the including of all human activities and related services

256 of nature in material flows accounting. Omitting any direct or indirect flows for pragmatic

257 reasons increase the part of "hidden" flows, the ones that could precisely be the most relevant

258 from a perspective of local or disp laced impacts.

259 The total material flow (TMR) per capita measures the efficiency of the contribution of the

260 population to its economy. This is certainly the most relevant indicator if we want to compare

261 a market economy (a "developed" country) with an autarkical village whose economy is only

262 marginally monetized. TMR could also be divided by hectares or by gross domestic product.

263 For further discussion, let us use here the same metric for TMR as in reference studies

264 (excluding air and water, including hidden flows) in order to be able to discuss the most

265 popular eco-efficiency indicators. The TMR per capita per year was $5 \mathrm{tcap}^{-1} \mathrm{y}^{-1}$ in Sarowar, 
against respectively $84,46,86$ and $84 \mathrm{tcap}^{-1} \mathrm{y}^{-1}$ in USA, Japan, Germany and Netherlands

267 (table 3 ). The intensity of material requirement per surface is only $7 \mathrm{tha}^{-1}$ for Sarowar, against

268 respectively $22,151,189$ and $307 \mathrm{t} \mathrm{ha}^{-1}$ for the developed countries considered. Note that for

269 Sarowar, this amount is of the same order of magnitude as the potential net primary

270 productivity of the agro-ecosystem, as measured in an associated culture of sorghum, beans

271 (dolichos lablab), maize and fibre plants in a kitchen garden $\left(7.1 \mathrm{tha}^{-1}\right)$. In developed

272 countries, the larger amount can be explained by a potentially quicker turnover of non-biotic material flows.

274 The common indicator of eco-efficiency or material inten sity (TMR per unit of GDP)

275 provides contrasted results. Following th is indicator calculated on the basis of GDP at the 276 current exchange rate, the tribal village of 1983 seemed much less efficient than developed 277 countries of 1991. Its denominator (GDP) being very small because of the low monetization 278 rate of its economy, and its material inputs being relatively high in its context of luxurious 279 nature, its TMR/GDP is immense: $70 \mathrm{~kg} \mathrm{\$}^{-1}$, compared to the $3 \mathrm{~kg} \$^{-1}, 3.4 \mathrm{~kg} \$^{-1}, 3.3 \mathrm{~kg} \$^{-1}$ 280 and $3.2 \mathrm{~kg} \mathrm{\$}^{-1}$ respectively for Japan, USA, Germany and the Netherlands. Thus, to produce 1 281 dollar of monetary revenue, Sarowar seemed to use 20 times more material than The 282 Netherlands. For cross-country comparison of GDP, the use of Purchasing Power Parity is 283 more appropriate [46]. The UN SNA (System of National Accounts) defines a PPP as a price 284 relative which measures the number of units in country B's currency that are needed in 285 country B to purchase the same quantity of an individual good or service as what 1 unit of 286 country A's currency will purchase in country A. Whereas the GDP of developed countries do 287 not change much when applying PPP, the Indian GDP is corrected by a factor 4 [47, 48]. The 288 comparable material intensity (in PPP) is then respectively $18 \mathrm{~kg} \mathrm{\$}^{-1}, 3.4 \mathrm{~kg} \mathrm{~S}^{-1}, 3.2 \mathrm{~kg} \mathrm{\$ ^{-1 } , 3 . 7}$

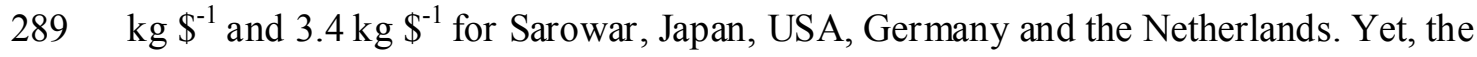
290 material in tensity of the tribal economy, expressed in PPP, was still 6 times bigger than in modern economies. It should be noted that Sarowar was relatively well monetized if

292 compared with surrounding villages not accessible by road. An ances tral economy with no 293 money would give an infinite material in tensity following this calculation.

294 Given the assumption that GDP does not represent the reality of the economy (in terms of 295 providing goods and services for human well-being), neither in autarkical villages, nor in 296 modern economies, a suitable solution could be to use an adjusted GDP, as a denominator to 297 calculate the material intensity. This adjusted GDP[49-53] would for example exclude 298 defensive expenditures (which is important for developing countries) and include a 299 monetization of autark ic work. For example, in the works on adjusted GDP, the monetization 
300 of hous ehold labour is taken considering local rates for housekeepers. Since rates for

301 housekeepers are not comparable between countries, this would introduce another type of

302 bias. In order to give comparable results between countries, a hypothetical adjusted GDP

303 would, in turn, need to be calculated in PPP. We do not enter into the debate on adjusted

304 GDPs here.

305 The calculation in this study shows the limits of the economic efficiency concept applied to

306 non-market economies. Moreover, even market economies include significant non-market

307 economic flows [49-54]. Here we can directly question the global relevance of the concept of

308 dematerialization of the economy as expressed by TMR/GDP. Following this indicator,

309 developed countries would be, by far, in advance, regarding dematerialization, even if they

310 remain the biggest users of materials from a global (absolute data) and relative (per capita)

311 point of view. We have seen (table 3 ) that per capita, the tribes of Sarowar use about 10-16

312 times less material than the mean Occidental inhabitant, and even 5-10 times less if only

313 direct input (grand total commodities) is taken into account. We show in the last row of table

3143 a possible wrong comparison of apparent intensity of air used (related to intensity of carbon

315 emission), where Sarowar seems 100 times more air-intensive than developed countries. The

316 apparent air use (thus the $\mathrm{CO} 2$ emissions) per capita is of the same magnitude than the per

317 capita use (or emissions) of industrial economies. The difference is however qualitative since

318 we have in Sarowar renewable air uses, thus accounting for zero in greenhouse gas

319 accounting. This kind of comparison would be twice wrong: wrong for the numerator

320 (comparing recyclable use to irreversible use) and wrong for the denominator (using GDP as a

321 measure of the economy).

322 The concept of in tensity, using two different units in the same ratio, implies the hypothesis of

323 substitutability between factors. For example, reducing TMR or increasing the population can

324 obtain reducing the TMR per capita. Reducing the TMR or increasing the GDP can obtain

325 reducing the TMR per GDP. Is it good for sustainable development to increase the population

326 or the GDP? This fundamental question is not raised in these kinds of ratios.

327 Acknowledging that the GDP is not a relevant measure of life satisfaction [55], one can

328 suggest using the concept of dematerialization of life satisfaction, of human well being, of

329 human development or of any corrected GDP, in dematerialization studies. Using different

330 dimension, not mixing different indicators in the same ratio, avoids the illusion of perfect

331 substitutability between the economy and the environment. The goal being to reduce the

332 material impact of whatever human ideal, these two indicators (environment and human well-

333 being) should remain in separate dimensions. Examples of multidimensional tools are the 
334 multi-criteria analysis [56] or graphic representation where human well-being and ecological

335 well-being are presented side by side like in Prescott Allen [57].

\section{Conclusion}

337 We presented a material flow accounting of a semi-autarkic Indian village, based on a former

338 human-ecological survey. Such material is available in other studies in human ecology.

339 Traditional human ecosystem measurements can serve as a basic comparison point, and we

340 used it to test common dematerialization indicators. We showed the importance of counting as

341 much direct and indirect flows as possible. In particular, hidden flows, embedded in imports

342 and exports, and air flows can be important from their impact point of view. Water flows

343 should be included for the same reason. Qualitative aspects should always be evaluated. For

344 example, open burning is associated to incomplete combustion and greater toxic emissions.

345 We showed that the limit of the eco-efficiency indicator mainly resides in the different

346 degrees of monetization of the economies. In incompletely monetized economies, this

347 indicator is highly biased by the underlying non-market material flows. We question the use

348 of ratios of non-substitutable factors in dematerialization assessment and we suggest the use

349 of multi-criteria analysis instead.

\section{Acknowledgments}

351 The Lefranc Foundation financed our stay in 1982-1983. Université Libre de Bruxelles

352 financed the participation of one of us in the Ninth Biannual Conference on "Ecological

353 Economics and Human Well-being” 15-18 December 2006, New Delhi, where we presented a

354 first version of this paper. Participants of this conference and an anonymous referee gave us

355 valuable comments.

\section{References}

357 1. Adriaanse, A., et al., Resources Flows: The Material Basis Of Industrial Economies.

358 1997, Washington DC: WRI. 66 pp.

359 2. Matthews, E., et al., The weight of Nations. Material outflows from indus trial

360 economies. Washington DC. 2000, Washington DC: World Resources Institute. 126

$361 \quad$ pp.

362 3. Haberl, H., et al., Progress towards sustainability? What the conceptual framework of

363 material and energy flow accounting (MFEA) can offer. Land Use Policy, 2004. 21: p.

364 199-213.

365 4. Wackernagel, M. and W.E. Rees, Our Ecological footprint: Reducing Human Impact

$366 \quad$ on the earth. 1996, Philadelphia: New Society Publishers.

367 5. Daly, H.E., Steady-state economics. San Francisco. 1977: Freeman. 
6. Meadows, D.H., et al., The Limits to Growth: A Report for the Club of Rome's Project on the Predicament of Mankind Universe Books. 1972, New York: Mankind Universe Books.

7. Odend'hal, S., Energetics of Indian Cattle in Their Environment. Human Ecology, 1972. 1: p. 3-22.

8. $\quad$ Duvigneaud, P., La syn thèse écologique. 1984, Paris: Doin. 380 pp.

9. Bartelmus, P., Dematerialization and capital maintenance: two sides of the sustainability coin. Ecological Economics, 2003. 46: p. 61-81.

10. Eurostat, Economy-Wide Material Flow Accounts and Derive Indicators, a Methodological Guide. 2001, Luxembourg: European Community.

11. Bringezu, S. and H. Schütz, in Resources Flows: The Material Basis Of Industrial Economies, A. Adriaanse, et al., Editors. 1997, Wuppertal Institute: Washington DC. p. 28.

12. Pandeya, S.C., et al., Final report of the research project on Genecology and Autecology of anjan grass (cenchrus ciliaris) complex in western india. 1977, Department of biosciences, Saurashtra university: Rajk ot. p. 453 pp.

13. Seshadri, C.V., Report of the Murugappa chettiar research centre. 1978: Madras, India.

14. Ravindranath, N.H., et al., An Indian village agricultural ecosystem - case study of Ungra village. 1980, Indian Institute of Science, A.S.T.R.A.: Bangalore.

15. Ravindranath, N.H., et al., An Indian village agricultural ecosystem-case study of Ungra village, Part I: Main observations. Biomass, 1981. 1(1): p. 61-76.

16. Reddy, A.K.N., An Indian village agricultural ecosystem-case study of Ungra village, Part II: Discussion. Biomass, 1981. 1(1): p. 77-88.

17. Briscoe, J., Population and development review, 1979. 5: p. 615.

18. $\quad \mathrm{Ba}, \mathrm{M} .$, Approche écoénergétique d'unécosystème sahélien. Plaine de M'Pourie (Mauritanie). Environn ement africain-Etudes et recherches, ed. ENDA. Vol. 79. 1979, Dakar: ENDA. 52.

19. He, X., Y. Xu, and X. Zhang, Traditional farming system for soil conservation on slope farmland in southwestern China. Soil and Tillage Research, 2007.94(1): p. 193200.

20. Dash, S.S. and M.K. Misra, Studies on hill agro-ecosystems of three tribal villages on the Eastern Ghats of Orissa, India. Agriculture, Ecosystems \& Environment, 2001. 86(3): p. 287-302.

21. Tripathi, R.S. and V.K. Sah, Material and energy flows in high-hill, mid-hill and valley farming systems of Garhwal Himalaya. Agriculture, Ecosystems \& Environment, 2001. 86(1): p. 75-91.

22. Maikhuri, R.K., Eco-energetic analysis of village ecosystem of different traditional societies of Northeast India. En ergy, 1996. 21(12): p. 1287-1297.

23. Pannu, C.J.S., et al., Energy use pattern for a selected village in the cotton-belt of Punjab. Energy, 1993. 18(11): p. 1113-1117.

24. Nayak, S.P., S.K. Nisanka, and M.K. Misra, Biomass and energy dynamics in a tribal village ecosystem of Orissa, India. Biomass and Bioenergy, 1993. 4(1): p. 23-34.

25. Nisanka, S.K., M.K. Misra, and N.C. Sahu, Economics offuel energy in an indian village ecosystem. Bioresource Technology, 1992.39(3): p. 249-261.

26. Mishra, B.K. and P.S. Ramakrishnan, Energy flow through a village ecosystem with slash and burn agriculture in North-eastern India. Agricultural Systems, 1982. 9(1): p. 57-72.

27. Nisanka, S.K. and M.K. Misra, Ecological study of an Indian village ecosystem: Biomass production and consumption. Biomass, 1990. 23(2): p. 117-136. 
418

419

420

421

422

423

424

425

426

427

428

429

430

431

432

433

434

435

436

437

438

439

440

441

442

443

444

445

446

447

448

449

450

451

452

453

454

455

456

457

458

459

460

461

462

463

464

465

466
28. Grünbühel, C., et al., Socio-economic methabolism and colonization of natural processes in Sangsaeng village: material and energy flows, land use, and cultural change in Northeast Tailand. Human Ecology, 2003.31(1): p. 53-86.

29. Maikhuri, R.K. and P.S. Ramakrishnan, Comparative analysis of the village ecosystem function of different tribes living in the same area in Arunachal Pradesh in Northeastern India. Agricultural Systems, 1991. 35(4): p. 377-399.

30. Government_of_Gujarat, Dangs District. Gujarat State Gazetteers. 1971, Ahmedabad: Government Printing, Stationary and Publications. 505.

31. Pand eya, S.C. and K. Kuruvilla. Natural forest communities, their net hole biomass and status of their underlying biogenic salts in Dangs forest, Gujarat. in Symp. recent adv. trop. ecol. 1968. Varanasi.

32. Kestemont, B., Sarowar, village de l'ouest de l'Inde: Contribution à l'étude d'un agroécosystème traditionnel: l'anthropocénose, la zoocénose, l'ager, ... in Section interfacultaire d'agronomie. 1983, ULB: Bruxelles. p. 187 pp.

33. Rao, B., Land of the Rising Rupee? Global Vistas, 2003. 2(1): p. 17.

34. Kerckhove, M. and B. Kestemont, Sarowar, an agrosilvopastoral ecosystem. 1984: Bruxelles.p. 19 pp.

35. FAO and OMS, Besoins énergétiques et besoins en protéines. Alimentation et nutrition. Vol. 7. 1973, Rome: FAO-OMS. 123.

36. Kestemont, B., L. Frendo, and E. Zaccaï, Indicateurs des impacts du développement sur l'environnement: une comparaison Afrique-Europe. VertigO, 2006. 7(2): p. 14.

37. Vitousek, P.M., et al., Human domination on Earth's Ecosystems. Science, 1997. 277: p. 494-499.

38. Simoneit, B.R.T., Biomass burning -- a review of organic tracers for smoke from incomplete combustion. Applied Geochemistry, 2002. 17(3): p. 129-162.

39. Cheung, V.T.F. and T. Wang, Observational study of ozone pollution at a rural site in the Yangtze Delta of China. Atmospheric Environment, 2001. 35(29): p. 4947-4958.

40. Korontzi, S., et al., Modeling and sensitivity analysis of fire emissions in southern Africa during SAFARI 2000. Remote Sensing of Environment

Forest Fire Prevention and Assessment, 2004. 92(3): p. 376-396.

41. Lavric, E.D., A.A. Konnov, and J.D. Ruyck, Dioxin levels in wood combustion - a review. Biomass \& Bioenergy, 2004. 26: p. 115-145.

42. Edwards, R.D., et al., Implications of changes in household stoves and fuel use in China. Energy Policy, 2004. 32(3): p. 395-411.

43. Martin ez-Allier, J., The environmentalism of the poor. 2002, Cheltenham: Edward Elgar.

44. WWF, Living planet report 2006. 2006: Gland. 44.

45. European_Union, Regulation 2150/2002 of the Council and the Parliament on waste statistics. 2002, Brussels: Eurostat.

46. Moll, S. and S. Bringezu, Agregated Indicators for Ressource Use and Resource Productivity. Their meaning, cross-country comparability, and potential driving factors., in Working Paper, P. Kazmierczyk, Editor. 2005, European Env ironment Agency: Copenhaegen. p. 28 pp.

47. Ratnababou, C., Foreign Exchange Rates and Purchasing Power Parity. Global Vistas, 2003. 2(1): p. 3-6.

48. Eurostat, New Cronos On-line database. 2004.

49. Daly, H.E. and J. Cobb, J.B., For the Common Good: Redirecting the economy towards Community, the Environment, and a Sustainable Future. 1989, Boston: Beacon Press. 486. 
50. Cobb, C. and J.B. Cobb Jr., The Green National Product: A Proposed Index of Sustainable Economic Welfare. 1994, New York: Univ ersity Press of America. 343.

51. Sto ckhammer, et al., The index of sustainable economic welfare. ISEW as an alternative to GDP in measuring economic welfare. The results of the Austrian revised ISEW calculation 1955-1992. Ecological Economics 1997. 21(1): p. 19-34.

52. Hamilton, C., The genu ine progress indicator methodological developments and results from Australia. Ecological Economics 1999. 30(1): p. 13-28.

53. Neumayer, E., On the methodology of ISEW, GPI and related measures: some constructive suggestions and some doubt on the 'threshold' hypothesis. Ecological Economics 2000.34(3): p. 347-361.

54. Temple, D. and M. Chabal, La réciprocité et la naissance des valeurs humaines. 1995, Paris: L'Harmattan. 263.

55. Vemuri, A.W. and R. Costanza, The role of human, social, built, and natural capital in exlpaining life satisfaction at the country level: Towards a National Well-Being Index (NWI). Ecological Economics, 2006. 58: p. 119-133.

56. Vincke, P., Analysis of multi-criteria decision aid in Europe. European Journal of Operational Research, 1986. 25: p. 160-168.

57. Prescott-Allen, R., The Well-being of Nations. A Country-by-Country Index of Quality of Life and the Environment. 2003, Washington: Island Press. 342. 


\section{$487 \quad$ Tables}

488 Table 1: Material flow accounts of Sarowar 1983, compared with the Netherlands 1991

\begin{tabular}{|c|c|c|c|}
\hline & $\begin{array}{l}\text { Sarowar } \\
\text { (t DM) }\end{array}$ & $\begin{array}{l}\text { Sarowar } \\
\left(\mathrm{t} \text { cap }^{-1}\right)\end{array}$ & $\begin{array}{l}\text { Neth } \\
\text { s (t c }\end{array}$ \\
\hline INPUTS & 10603 & 15,8 & 84,9 \\
\hline Imports & 120 & 0,2 & 20,2 \\
\hline Foreign hidden flows & 360 & 0,5 & 42,1 \\
\hline Abiotic raw material & 0 & 0,0 & 12,3 \\
\hline Biotic raw material (dry weight) & 2761 & 4,1 & 0,4 \\
\hline Air & 7363 & 11,0 & 9,8 \\
\hline Erosion & 0 & 0,0 & 0,1 \\
\hline Recycling & & & $-2,3$ \\
\hline Hidden flows avoided by recycling & & & $-2,7$ \\
\hline \multicolumn{4}{|l|}{ ECONOMY } \\
\hline Stock variation & +40 & $+0,1$ & $+5,0$ \\
\hline OUTPUT & 10564 & 15,8 & 66,8 \\
\hline Exports & 208 & 0,3 & 15,8 \\
\hline Waste disposal (excl. Incineration) & 5 & 0,0 & 1,7 \\
\hline Erosion & 0 & 0,0 & 0,1 \\
\hline Waste (biotic), water emissions & 220 & 0,3 & 0,7 \\
\hline Air emissions & 10124 & 15,1 & 19,4 \\
\hline Hidden flows export & 8 & 0,0 & 29,1 \\
\hline
\end{tabular}

489 Sources: authors and [1]

490 Here, the biotic material for The Netherlands is here expressed in dry weight estimating $31 \%$

491 of dry matter in an average of grains and grass production for this country (see table 2) 
492 Table 2

493 Biotic material requirement (1000 metric tons) in The Netherlands 1991.

Renewable

$\begin{array}{llll}\text { 1. Plant Biomass (fresh weight) } & \% \text { DM } & \text { Fresh weight Dry weight } \\ \text { Grass } & 20 \% & 8946 & 1789 \\ \text { Wheat } & 88 \% & 1144 & 1007 \\ \text { Rye } & 88 \% & 41 & 36 \\ \text { Barley } & 88 \% & 288 & 253 \\ \text { Oat } & 88 \% & 22 & 19 \\ \text { Peas } & 88 \% & 39 & 34 \\ \text { Bean } & 88 \% & 11 & 10 \\ \text { Cole seed } & 88 \% & 25 & 22 \\ \text { Flax } & 88 \% & 135 & 119 \\ \text { Potatoes } & 20 \% & 20435 & 4087 \\ \text { Potatoes (industrial) } & 20 \% & 8886 & 1777 \\ \text { Sugar beets } & 20 \% & 28756 & 5751 \\ \text { Onion } & 10 \% & 4466 & 447 \\ \text { Corn (for cattle) } & 60 \% & 35660 & 21396 \\ \text { Vegetables } & 20 \% & 24962 & 4992 \\ \text { Fruit } & 20 \% & 2100 & 420 \\ \text { II. Plant Biomass, Wild Harv est Wood } 88 \% & 551 & 485 \\ \text { II. Animal Biomass, Wild Harvest Fish30\% } & 740 & 222 \\ \text { Total Renewable } & 31 \% & 137207 & 42867 \\ \text { So } & 250 & \end{array}$

494 Source: [1] for fresh weight, authors es timates for dry weights 
496 Table 3: Comparison of material flows (excluding air and water) between a traditional

497 autarkical Indian village (1983) and four developed countries (1991).

\begin{tabular}{|c|c|c|c|c|c|}
\hline & USA & Japan & Germany & $\begin{array}{l}\text { Netherland } \\
\text { s }\end{array}$ & Sarowar \\
\hline Unit of raw data & $\operatorname{tx} 10^{6}$ & $\mathrm{t} \times 10^{6}$ & $\mathrm{t} \times 10^{6}$ & $\operatorname{tx} 10^{6}$ & $\mathrm{t}$ \\
\hline Total domestic commodities & 4581 & 1424 & 1367 & 271 & 2761 \\
\hline Total foreign commodities & 568 & 710 & 406 & 303 & 120 \\
\hline Grand total commodities & 5149 & 2133 & 1773 & 574 & 2881 \\
\hline Grand total commodities per cap $\left(\mathrm{t}\right.$ cap $\left.^{-1}\right)$ & 20 & 17 & 22 & 38 & 4 \\
\hline Domestic hidden flows & 15494 & 1143 & 2961 & 69 & 0 \\
\hline Foreign hidden flows & 594 & 2439 & 2030 & 632 & 360 \\
\hline Total hidden flows & 16088 & 3582 & 4991 & 701 & 360 \\
\hline Tot. Hidden flows/tot. Comm. & 3 & 2 & 3 & 1 & 0,04 \\
\hline TMR (commodities + hidden flows) & 21237 & 5715 & 6764 & 1275 & 3241 \\
\hline TMR per capita $\left(\mathrm{t} \mathrm{cap}^{-1}\right)$ & 84 & 46 & 86 & 84 & 5 \\
\hline TMR per GDP $\left(\mathrm{kg} \mathrm{S}^{-1}\right)$ & 3,4 & 3,0 & 3,3 & 3,2 & 70 \\
\hline TMR per GDP PPP $\left(\mathrm{kg} \$^{-1}\right)$ & 3,4 & 4,2 & 3,7 & 3,4 & 18 \\
\hline TMR per surface $\left(\mathrm{t} \mathrm{ha}^{-1}\right)$ & 22 & 151 & 189 & 307 & 7 \\
\hline Air*** & 3949 & 843 & 1095 & 149 & 7363 \\
\hline Air $\left(\mathrm{tcap}^{-1}\right)$ & 14 & 7 & 14 & 10 & 11 \\
\hline Air / GDP PPP $\left(\mathrm{kg} \mathrm{\$}^{-1}\right)$ & 0.6 & 0.4 & 0.6 & 0.4 & 41 \\
\hline \multirow{3}{*}{\multicolumn{6}{|c|}{$\begin{array}{l}\text { * Limited to erosion due to human activities. Supposed negligible in Sarowar at this time, due } \\
\text { to cultivation on moderated slopes and terraces with associated cultiv ation and tree cover. } \\
\text { ** Direct foreign input } x \text { hidden flow/indirect input of the USA (hidden flow from equivalent }\end{array}$}} \\
\hline & & & & & \\
\hline & & & & & \\
\hline \multicolumn{6}{|l|}{ US exportation) } \\
\hline \multicolumn{6}{|c|}{ *** As an indicative proxy, air data for USA and Japan were calculated using the $\mathrm{O} 2$} \\
\hline equivalent of CO2 emissions (1997) give & by [57] & & & & \\
\hline urce: authors and [1] & & & & & \\
\hline
\end{tabular}




\section{Figures}

506 [Separate file ecosystem4.jpg]

507 Figure 1: Ecosystem Sarowar (flows expressed in tons dry matters) after [34] 


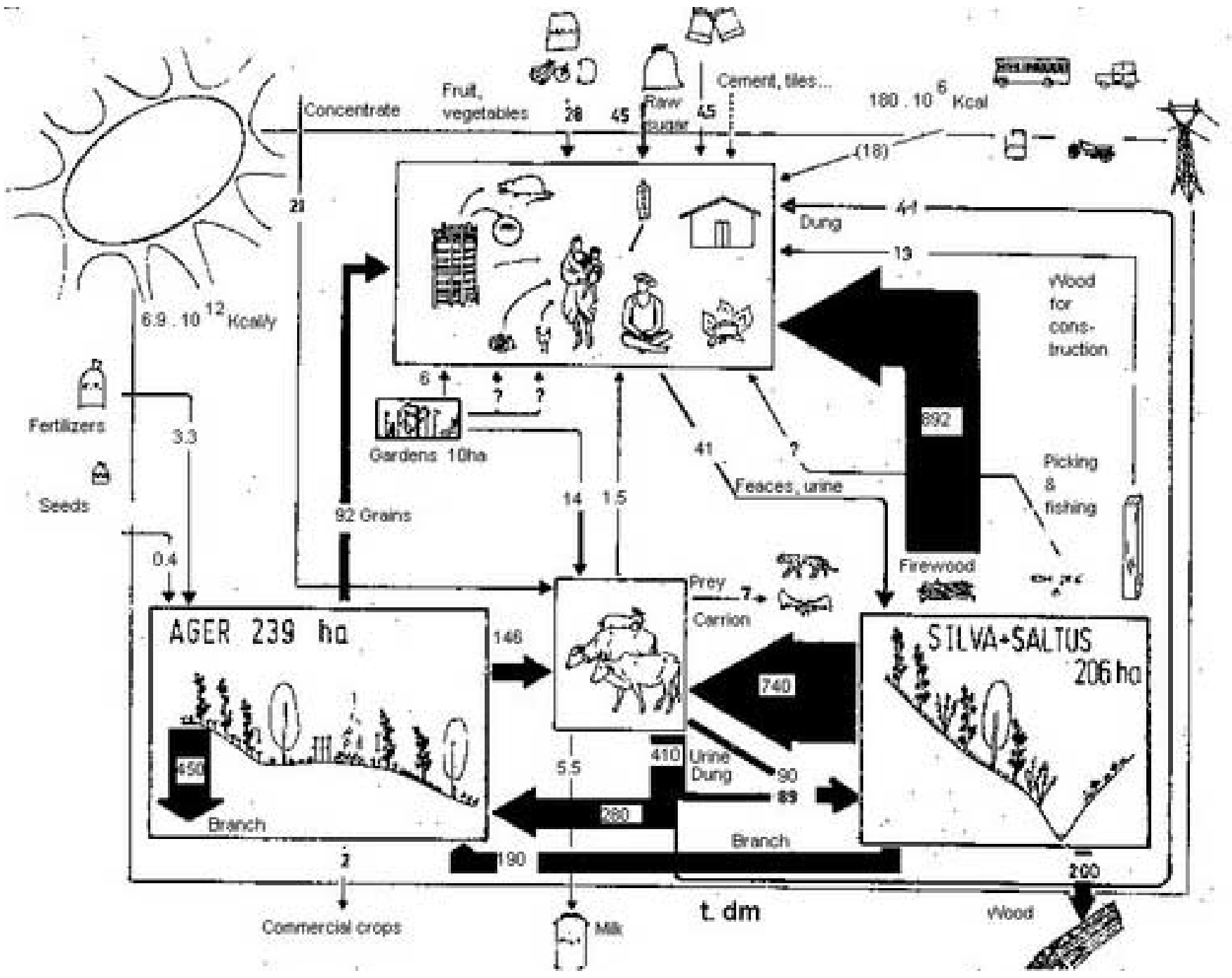

